\title{
Evolution of Chinese Ghost Cities
}

Opportunity for a Paradigm Shift? The Case of Changzhou

\section{Li Mingye}

\section{(2) OpenEdition}

\section{Journals}

Electronic version

URL: http://journals.openedition.org/chinaperspectives/7209

DOI: 10.4000/chinaperspectives.7209

ISSN: 1996-4617

\section{Publisher}

Centre d'étude français sur la Chine contemporaine

\section{Printed version}

Date of publication: 1 March 2017

Number of pages: 69-78

ISSN: 2070-3449

\section{Electronic reference}

Li Mingye, «Evolution of Chinese Ghost Cities », China Perspectives [Online], 2017/1 | 2017, Online since 01 March 2018, connection on 10 December 2020. URL : http://journals.openedition.org/ chinaperspectives/7209; DOI : https://doi.org/10.4000/chinaperspectives.7209

(C) All rights reserved 


\title{
Evolution of Chinese Ghost Cities
}

\author{
Opportunity for a Paradigm Shift? The Case of Changzhou
}

\author{
LI MINGYE
}

\begin{abstract}
In the late 2000s, the phenomenon of ghost cities emerged in China, including not only boomtowns such as Ordos but also "ordinary" third- and fourth-tier cities such as Changzhou. Based on a conceptual framework of China's land-driven growth machine under entrepreneurial governance, we update the ghost city phenomenon through an in-depth empirical study of a third-tier city, Changzhou. The objective of this paper is to expand our understanding of how excessive accumulation of real estate assets has come to dominate the landscape of this type of city against the background of China's economic slowdown. The author argues that overbuilding is due to the malfunction of the classic urban expansion model under entrepreneurial governance. In the case of Changzhou, the local government continued massive "sales" of residential and commercial land while effective housing demand was declining due to slowdowns in the local manufacturing industry and in population growth. In response to the "New Normal" (1) advocated by the central government, the government of Changzhou redirected its land and housing policy. Nevertheless, more profound reforms are needed to change the paradigm of growth-oriented urbanism.
\end{abstract}

KEYWORDS: Ghost city, urban expansion, real estate, growth machine, entrepreneurial governance, Changzhou, China.

\section{Introduction}

S ince the late 2000s, the ghost city phenomenon in China has been widely reported by international media. The phenomenon has also attracted interest from the scientific community. Most of these contributions focused on extreme cases, including the resource-based boomtown Ordos municipality, (2) a government-led mega urban project, Zhengdong New District, (3) and a county relocated after an earthquake, New Beichuan. (4) Yet, these accounts focusing on extreme cases cannot give a fair representation of the phenomenon as a whole. ${ }^{(5)}$ In fact, more and more "ordinary" cities have appeared in the list of ghost cities since 2010. In 2014, 50 Chinese cities were labelled as ghost cities by China Urban Construction Statistical Yearbook, including 42 prefecture-level cities and eight countylevel cities. ${ }^{(6)}$ Among them, only one city is regarded as a second-tier city, while the rest are third- and fourth-tier or even fifth-and sixth-tier cities. ${ }^{(7)}$

Despite the above reports, there are methodological difficulties in assessing the scope of the ghost city phenomenon, in particular the lack of a standard definition of a "ghost city." Shepard Wade listed several definitions of ghost cities in his book. ${ }^{(8)}$ One point is clear: it is necessary to redefine the ghost city, which was originally considered "a place that has died" or "an abandoned city." One common feature of Chinese ghost cities is high vacancy rates in their residential developments. However, the Chinese government has not published any data related to housing vacancy rates. Another definition is based on the population density of an urban built-up area. For example, the population density in the built-up area of the 50 ghost cities identified in 2014 was between 700 and 5,400 inhabitants per $\mathrm{km}^{2}$, far below the 10,000 inhabitants per $\mathrm{km}^{2}$ required by the National Plan of New Urbanization. ${ }^{(9)}$ An alternative method has also been used for measuring ghost cities through big data. ${ }^{(10)}$ In this study, the main concern is the formation of the ghost city phenomenon in a third-tier city with the evolution of macro-economic context. Thus, we opt for indicators such as housing stock and land supply to assess the process of forming a ghost city, as well as indicators such as population density and land use to examine the phenomenon on the urban scale.

Excess housing supply in a portion of Chinese cities attracted the attention of the central government. At the $11^{\text {th }}$ meeting of the Central Finance and Economy Leading Group on 10 November 2015, President Xi Jinping stressed that China should strengthen structural reform on the supply front to increase the quality and efficiency of the supply system in the New Normal era. ${ }^{111}$ One of the key tasks of this reform is to promote the absorption of excess production capacity. With regard to the real estate industry, "reducing stock (qukucun)" is seen as a critical measure to reach this target.

1. In 2014, President Xi Jinping proclaimed that China was entering a "New Normal." The term was indicative of the Chinese government's anticipation of moderate but more balanced economic growth as opposed to the high-speed growth of the last three decades. Source:Wang Jinwen, "The 'New' and 'Normal' in the discourse of Xi Jinping about 'New Normal,'" http://www. chinanews.com/gn/2014/08-10/6477530.shtml (accessed on December 6, 2016)

2. Woodworth Max D., "Ordos Municipality: A market-era resource boomtown," Cities, 43, 115-132, 2015, Yu Hong. "China's 'Chost Cities'," East Asian Policy, Vol. 6, No. 2, 2014, pp. 33-42.

3. Charlie Q. L. Xue, Wang Ying, and Luther Tsai, "Building new towns in China - A case study of Zhengdong New District," Cities, Vol. 30, 2013, pp. 223-232.

4. Christian Sorace and William Hurst, "China's phantom urbanisation and the pathology of ghost cities," Journal of Contemporary Asia, Vol. 46, No. 2, 2016, pp. 304-322.

5. Wade Shepard, Ghost Cities of China, Zed Books, London, 2015.

6. Jie Mian, "The list of 50 Chinese ghost cities in 2015," http://finance.sina.com.cn/china/20151117/ 223123790511.shtml (accessed on 9 March 2016).

7. There is no official definition of first, second, third, fourth, fifth, and sixth- tier cities in China. The country's first-tier cities usually refer to Beijing, Shanghai, Guangzhou, and Shenzhen. Secondtier cities include major capital cities of each province or important large cities such as Tianjin, Nanjing, Chengdu, Wuhan, Hangzhou, and Chongqing. Third- and fourth-cities are usually the medium-sized prefectural-level cities of each province. Fifth- and sixth-tier cities are usually small prefectural-level cities and county-level cities.

8. Wade Shepard, Ghost Cities of China, op. cit.

9. "National Plan of New Urbanization (2014-2020)," http://politics.people.com.cn/n/2014/0317/ c1001-24649809.html (accessed on 28 December 2016).

10. Chi Guanghua, Zhengwei Wu, Yu Liu, and Haishan Wu, "Chost cities analysis based on positioning data in China," arXiv, 1510.08505 [cs.SI], 2015.

11. Yuan Can, "China's economy focuses more on reform of the supply front," http://en.people.cn/ n/2015/1209/c90000-8988260.html (accessed on 13 March 2016). 
Figure 1 - Permanent population density in different subdivisions of Changzhou city in 2014

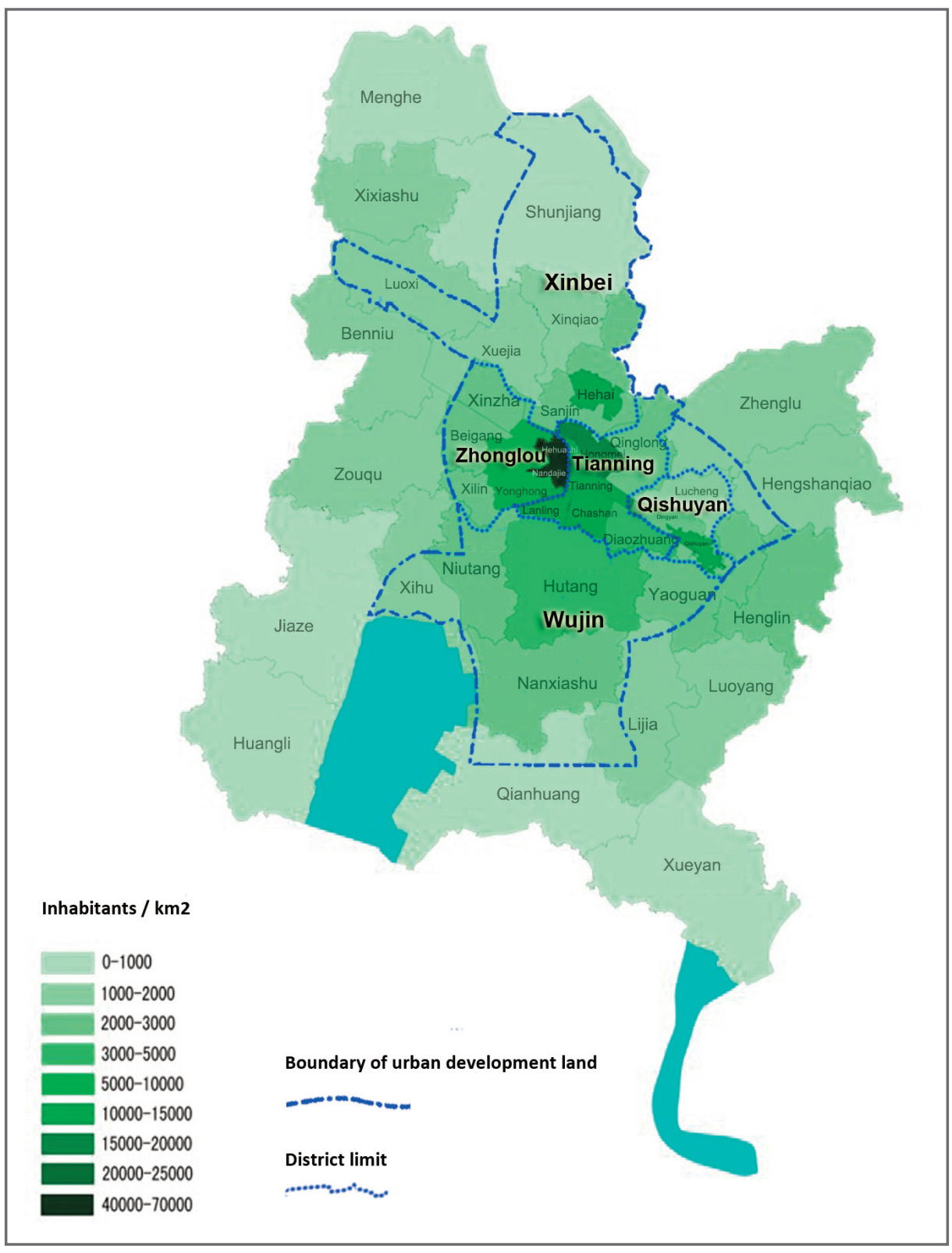

Source: adapted and translated by the author according to the CCPDI (2015) more than $20 \%{ }^{(15)}$ statistics showed that the excess supply of commodity housing was not an illusion. The city's commodity housing stock increased from 4.36 million $\mathrm{m}^{2}$ in 2006 to 10.12 million $\mathrm{m}^{2}$ in 2013 , representing an increase of $132 \%$ within eight years. The rotation time for destocking commodity housing inventory (shangpinzhufang qukucun zhouqi) (16) reached a peak in 2014 at 18 months, which was much higher than the reasonable range of 6 to 12 months. (17) Notwithstanding, it is an exaggeration to consider the entire city a ghost city, since the phenomenon is concentrated in the new districts. In 2014, the permanent population density of Wujin District was 5,390 inhabitants $/ \mathrm{km}^{2}$, much lower than the districts in the city proper, which had a population density of more than 10,000 inhabitants $/ \mathrm{km}^{2}$ (figure 1). Given that, the paper examines the case of Changzhou with a focus on one of its new districts, Wujin, where the problem of overbuilding is more acute than in the city proper.

Based on a conceptual framework of China's land-driven growth machine under entrepreneurial governance, this paper aims to answer the following questions with an indepth empirical study: What is the process of forming a "ghost city" in the case of an ordinary third-tier city, Changzhou? What is the underlying reason for overbuilding in such a city against the background of slowdown in industrial and demographic growth? Are changes in housing and land policy in Changzhou under the New Normal a sign of paradigm shift in Chinese urbanism? To answer these questions, we start with a discussion on the land-driven growth machine and the urban form shaped by this mechanism. This echoes the view of scholars who attribute
Meanwhile, the National Plan of New Urbanisation (2014-2020) (12) proposed a more compact urban form by controlling urban development land per capita to within $100 \mathrm{~m}^{2}$, which is equivalent to a population density of 10,000 inhabitants per $\mathrm{km}^{2}$. These national policies implied the willingness of the central government to transform the current growth-oriented urbanisation model into a people-oriented one. In this light, it is necessary to take into consideration the changing macro-economic environment and its impact on land and housing policies at the local level.

Changzhou is a third-tier city ${ }^{(13)}$ located at the heart of the Yangtze River Delta. It was one of the first ghost cities reported by China's official CCTV in January 2013. ${ }^{(14)}$ The city was labelled a ghost city owing to an abundance of unoccupied residential projects, especially in its new districts. Although the local government argued that Changzhou's local real estate market was prosperous and the vacancy rate in residential areas was no
12. This urban development land use standard is stricter than that stipulated by the "Code for classification of urban land use and planning standards for development land (GB50137-2011)," promulgated in 2012. The latter stipulated maximum urban development land per capita of $105 \mathrm{~m}^{2}$ in a newly built city, $115 \mathrm{~m}^{2}$ in a capital city, and $150 \mathrm{~m}^{2}$ in some cities in remote border regions, mountainous regions, resource-based regions, and tourist areas. See "Code for classification of urban land use and planning standards for development land (GB50137-2011)."

13. Changzhou was described as a third-tier city in the classification published by the official website China.com: Cheng Xue, "List of Chinese first-tier, second-tier and third-tier cities in 2015," http://henan.china.com.cn/finance/2015/0624/519547.shtml (accessed on 29 December 2016).

14. CCTV, "Changzhou considered as another Ghost city, developers and investors gambling on housing price," http://house.ifeng.com/detail/2013_01_14/31165666_0.shtml, (accessed on 17 March 2016).

15. Ma Ben, "Changzhou was reported as ghost city by CCTV due to its high level of housing stock" http://news.xinhuanet.com/house/2013-01/15/c_124231924.htm, (accessed on 9 March 2016).

16. The rotation time for destocking commodity housing inventory is an indicator derived from industry and commonly used in China to measure the status of real estate market.

17. BHSREMC, 2015 nian Changzhoushi fangdichan shichang yunxing qingkuang baogao, (Annual report of real estate market in Changzhou city (2015)), intern document (in Chinese). 
the ghost city phenomenon to China's land-centred urbanisation of a speculative nature under developmentalism. ${ }^{(18)}$ Nonetheless, our study differs from the existing literature in the following aspects: first, rather than focusing on extreme forms of urban development, we update the ghost city phenomenon in mainland China by looking at an ordinary third-tier city, Changzhou, where vacancies are mainly connected with residential programs rather than "face projects" (mianzi gongcheng) for aesthetic purposes (sculptural landmarks such as museums, libraries, theatres, squares, etc.). This challenges the concept of "phantom urbanisation" based on the experience of Ordos and New Beichuan with an over-emphasis on the aesthetic urban form. ${ }^{(19)}$ Second, we situate the phenomenon in the context of the changing macro-economic environment and examine the dynamics of Changzhou's land and real estate market over the past decade. Given Changzhou's efforts to reduce housing stock under the New Normal, we also assess the effects of related measures and discuss the possibility of a paradigm shift from growth-oriented to people-oriented urbanisation. (20) Third, we highlight the heterogeneity of the ghost city phenomenon within the territory of Changzhou by focusing on its new district, Wujin. Compared to the city proper, the new district has been more prone to overbuilding due to a lax land control system and greater dependence on land finance.

This study used data provided by the Bureau of Housing Security and Real Estate Management of Changzhou (hereafter BHSREMC), Changzhou City Planning and Design Institute (hereafter CCPDI), and Municipal Bureau of Statistics of Changzhou (hereafter MBSC). In addition, semi-structured interviews with officials and urban planners from BHSREMC and CCPDI as well as on-site observation carried out by the author were employed for the study. The remainder of the paper proceeds as follows: first, we build a conceptual framework for an urban expansion model for third-and fourth-tier cities based on China's land-driven growth machine. In the second section, we investigate the case of Changzhou to illustrate the process of ghost city formation under entrepreneurial governance, with a focus on Wujin New District. Next, we examine changes in Changzhou's land and housing policies in the new context and discuss the possibility of a paradigm shift in Chinese urbanism.

\section{China's land-driven growth machine based on urban entrepreneurialism}

The concept of urban entrepreneurialism based on Western experience (21) has been widely used to describe China's growth-oriented urban governance. (22) In particular, Wu Fulong explicated the institutional set-up that has turned the city into a growth machine. (23) First, the official evaluation system that emphasises local economic performance drives officials to pursue GDP growth. Local leaders become virtual CEOs of "urban development corporations," endeavouring to improve the city's competitiveness. ${ }^{(24)}$ Second, pressure on local public finance drives the local government to initiate mega urban development projects to gain land revenue. Since the tax-sharing reforms in 1994, local governments have been allowed to keep revenue derived from land lease transactions to meet ongoing public expenditure. At the same time, economic devolution allowed the central government to delegate social and public services to the local governments. Consequently, the financing of urban infrastructure and facilities has depended greatly on this revenue, which accounts for a substantial share of municipal governments' total revenues. ${ }^{(25)}$ This institutional arrangement has transformed the Chinese city into a land-driven growth machine.

\section{Classic urban expansion model under entrepreneurial governance in China}

The land-driven growth machine has shaped the urban spatial pattern of Chinese cities. In the context of globalisation, China has accelerated the pace of industrialisation based on an export-oriented economy. The local government is enthusiastic about creating industrial zones to attract manufacturing activities and thus to stimulate the local economy. Owing to fierce inter-city competition, the common practice of local governments is to lease industrial land to investors at a cheap and subsidised price. (26) The aim is to use industrial development to stimulate the local economy as a whole, and use the "spill-over" effect to increase demand for housing and for commercial and retail space. (27) In contrast to cheap industrial land, residential and commercial land is leased by the local government at a higher market price to real estate developers. Due to fact that only the local government can convert rural land into state land for urban development, it usually pays relatively low compensation to the existing users, for example farmers. (28) The price gap constitutes the local government's land revenue, which is used to finance urban infrastructure and to provide public services. In this classic urban expansion model, industrial development is regarded as a driving force for the local economy, which is expected to attract both activities and population. Theoretically, residential and commercial land expands based on increasing housing demand and contributes to urban expansion in tandem with the expansion of industrial land (figure 2).

\section{Urban expansion model under entrepreneurial governance in Chinese third- and fourth-tier cities}

The ghost city phenomenon in most third- and fourth-tier cities is related to the rapid expansion of residential and commercial land and low housing demand. China's economic slowdown since 2010 has had an impact on the local economy of many third- and fourth-tier cities. While the Chinese

18. Yu Hong, "China's 'Chost Cities'," art. cit., pp. 33-42; Shin Hyun Bang, "Contesting speculative urbanisation and strategising discontents," City: Analysis of urban trends, culture, theory, policy, action, Vol. 18, No. 4-5, 2014, pp. 509-516.

19. Christian Sorace and William Hurst, "China's phantom urbanisation and the pathology of ghost cities," art. cit., 2016, pp. 304-322.

20. "Prime Minister Li Keqiang has promoted a new-type of 'people-oriented urbanization'," http://finance.q9.com/a/20130319/001198.htm (accessed on December 29, 2016).

21. Susan Fainstein, The city builders, Oxford, Blackwell Publishers, 1994; David Harvey, "From managerialism to entrepreneurialism:The transformation in the urban governance in late capitalism." Geografiska Annaler, Vol. 71, No. B, 1989, pp. 3-18.

22. Wu Fulong, "Re-orientation of the city plan: Strategic planning and design competition in China." Geoforum, Vol. 38, 2007, pp. 379-392.

23. Wu Fulong, Planning for Growth: Urban and Regional Planning in China, New York and London, Routledge, 2015, pp. 50-72.

24. Shuih-Shen Chien, "The isomorphism of local development policy: A case study of the formation and transformation of national development zones in post-Mao Jiangsu, China," Urban Studies, Vol. 45, No. 2, 2008, pp. 273-294.

25. Tao Ran, Su Fubing, Liu Mingxing, and Cao Guangzhong, "Land Leasing and Local Public Finance in China's Regional Development: Evidence from Prefecture-level Cities," Urban Studies, Vol. 47, No. 10, 2010, pp. 2217-2236; George Lin and Yi Fangxin "Urbanization of capital or capitalization on urban land? Land development and local public finance in urbanizing China," Urban Geography, Vol. 32, No. 1, 2011, pp. 50-79.

26. Zhang jingxiang, Zhao Dan, and Chen Hao, "Zengzhang zhuyi de zhongji yu zhongguo chengshiguihua de zhuanxing," (Termination of growth supremacism and transformation of China's urban planning) City Planning Review, Vol. 37, No. 1, 2013, pp. 45-55.

27. Wu Fulong, Planning for Growth: Urban and Regional Planning in China, op. cit., pp. 50-72.

28. Ibid. 


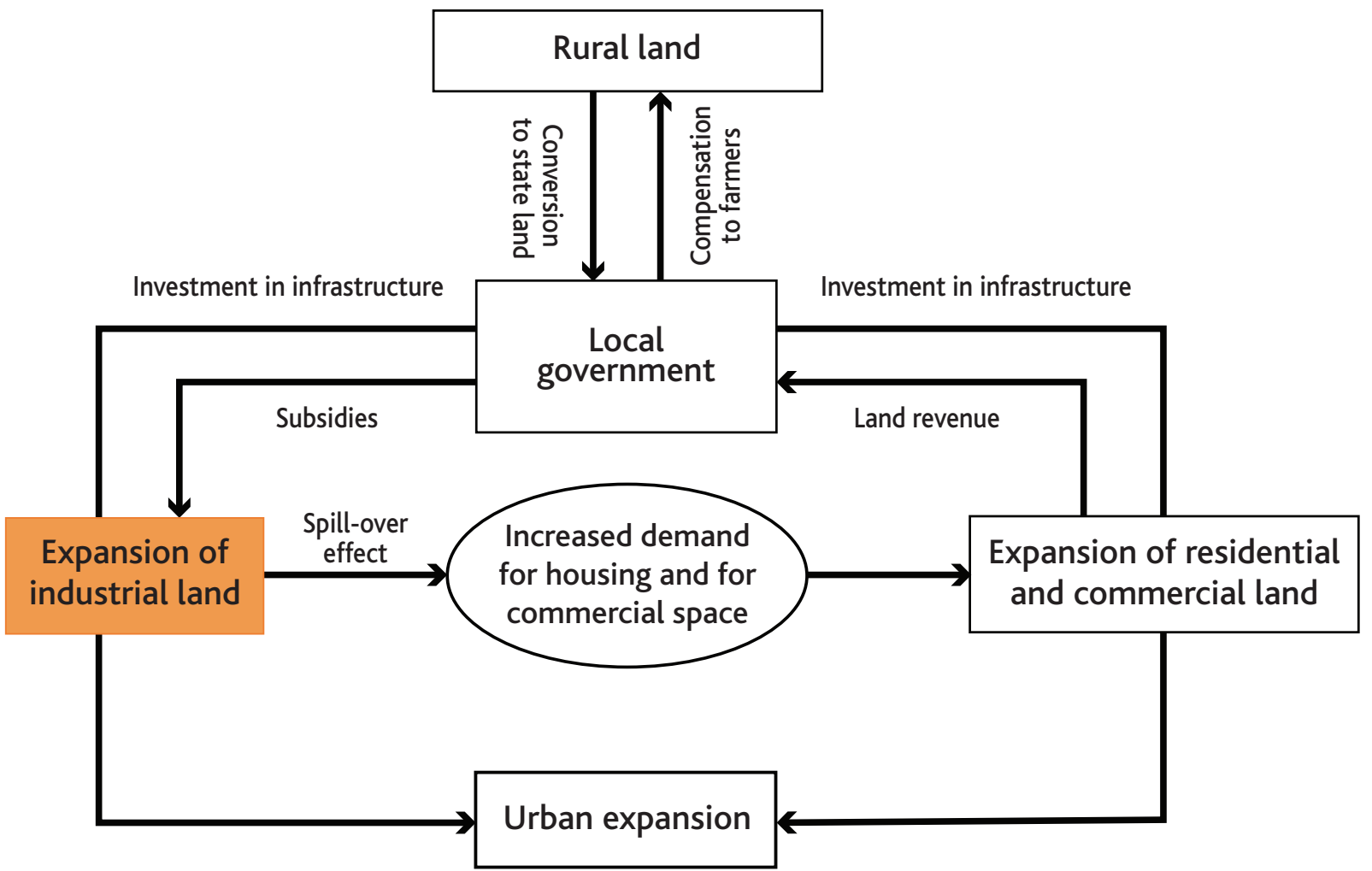

Source: compiled by the author according to Zhang Jingxiang, Zhao Dan, and Chen Hao, "Zengzhang zhuyi de zhongji yu zhongguo chengshiguihua de zhuanxing" (Termination of growth supremacism and transformation of China's urban planning), City Planning Review, Vol. 37, No. 1, 2013, pp. 45-55; Wu Fulong, Planning for Growth: Urban and Regional Planning in China, New-York and London, Routledge, 2015, pp. 50-72.

government attempts to transition from an export-driven economy to one based on domestic demand, the majority of these cities, based on exportoriented manufacturing, are facing the difficulty of economic restructuring. Consequently, the growth of the urban population has slowed down due to sluggish manufacturing sectors. Meanwhile, existing housing demand is not strong. On the one hand, homeownership in these cities is much higher than in first- and second-tier cities. On the other hand, speculative demand in these cities is lower than in first- and second-tier cities due to relatively moderate housing prices and low attractiveness. In addition, rural migrant workers, although frequently suffering from poor living conditions, (29) have few opportunities to own housing in urban destinations due to their poor economic conditions and institutional barriers. ${ }^{(30)}$ As a result, effective housing demand in third- and fourth-tier cities has been low.

Nevertheless, local governments in third- and fourth-tier cities have been keen to expand residential and commercial land over the past decade. As the monopolistic supplier in the primary land market, local governments control the quota of serviced residential and commercial land based on local economic needs rather than on effective housing demand. This is due to several overlapping factors.

First, as in most Chinese cities, urban expansion and real estate development have been used to promote the local economy in third- and fourthtier cities. Urbanisation has boosted China's industrial development and economic growth over the past three decades. Since the housing reforms in 1998, the urbanisation process has been accelerated by a booming real estate sector, which was identified as "the pillar industry of the national economy." (31) The contribution of this sector to national GDP increased from $4 \%$ in 1997 to 15\% in 2015. ${ }^{(32)}$ Despite a short decline between 2008 and
2009, the market was booming again after the intervention of the central government. Under these circumstances, local governments have encouraged real estate investment, especially in new districts and new towns, so as to boost local GDP, the top criterion of the official evaluation system. At the same time, urban expansion and real estate development can bring significant land revenue and fiscal revenue to local governments, allowing them to finance urban infrastructure and thus contribute to physical changes in the city - another criterion in the official evaluation system.

Second, in third- and fourth-tier cities, while industrial development has slowed down, the local economy has become more dependent on land finance and real estate development. Compared to first- and second-tier cities, third- and fourth-tier cities have more difficulty achieving economic restructuring and upgrading, given their lack of qualified professionals and high technology. Instead, real estate development constitutes a more efficient means of accumulation for local officials, who are more concerned about short-term economic growth and visible achievements. In other word, third- and fourth-tier cities remain in the process of commingling the primary circuit of low-cost labour-intensive production with the second circuit

29. Wang Yaping, "Living conditions of migrants in inland Chinese cities," Journal of Comparative Asian Development, 2/1, pp. 47-69, 2003; John. R. Logan and Susan S. Fainstein, (eds), "Introduction: Urban China in comparative perspective," in Urban China in transition, Oxford, Blackwell, 2008, pp. 1-23.

30. Lu Ping and Zhou Tao, "Housing for rural migrant workers: Consumption characteristics and supply policy," Urban Policy and Research, Vol. 26, No. 3, 2008, pp. 297-308

31. Li Mingye, "De la planification à la bulle immobilière: Le logement en Chine," Études Foncières, No. 151, 2011, pp. 27-33; State Council, Guowuyuan guanyu cujin fangdichan shichan chixu jiankang fazhan de tongzhi (Notice from the State Council on Promoting a Continuous and Healthy Development of the Real estate Market), 2003.

32. Natacha Aveline, "Centralité du foncier et dynamiques immobilières en Chine au prisme de l'Etat Développeur," article presented at the Colloque International Recherche et Régulation 2015, Paris. 
of investment in built environment. (33) This point echoes Lin and Zhang's findings that "the importance of land sales as a means of revenue generation has declined as the level of urban economic growth improves." (34)

Third, compared to first- and second-tier cities, third- and fourth-tier cities generally apply a less strict land control policy. In the case of the former, in order to maximise land revenue, local governments have released only a limited amount of urban land for housing and commercial development, which in turn results in high land prices, ${ }^{(35)}$ whereas in the case of the latter, given the moderate land prices, local governments have adopted an opposite strategy by releasing a large amount of residential and commercial land so as to increase total land revenue.

To sum up, under the current institutional system, urban expansion and real estate development are used by urban governments to boost the local economy. In the context of China's slowdown, reliance upon the real estate sector in Chinese third- and fourth-tier cities is more significant than in first- and second-tier cities. The residential real estate sector has replaced the manufacturing industry as the driving force of the local economy. As a result, residential and commercial land expands at a faster pace than the growth of housing demand in these cities. This has eventually led to overbuilding and even the ghost city phenomenon.

\section{Changzhou: Formation of a ghost city under entrepreneurial governance}

\section{A third-tier city in fierce inter-city competition}

Changzhou is a prefecture-level city located in the heart of the Yangtze Delta, midway between Nanjing and Shanghai. In 2014, the population of Changzhou municipality reached 4.69 million, of which 3.38 million lived in Changzhou City (shiqu). ${ }^{(36)}$ In 2014, Changzhou City had an urban development area of $326.6 \mathrm{~km}^{2}$, which consisted of the city proper covering the whole area of Tianning, Zhonglou, and Qishuyan districts, as well as part of its two new districts, Xinbei in the north and Wujin in the south. (37)

In the 1980s, Changzhou experienced a period of prosperity based on its fast industrialisation. Representing one third of the GDP of the province of Jiangsu, Changzhou was a star among industrial medium-sized cities at that time. ${ }^{(38)}$ However, the external environment changed rapidly. In the 1990s, a large number of local enterprises were defeated by foreign-invested enterprises in the Pearl River Delta and the lively private economy of the Wenzhou region. Since then, Changzhou has lagged behind.

In the 2000s, in a context of fierce inter-city competition, there was a strong willingness within the Changzhou government to enhance the city's economic competitiveness and to regain its leading place in the province. Nevertheless, constrained by fragmented governance and an unclear industrial strategy, the city has had difficulty changing its economic position in the region. In 2015, Changzhou ranked sixth among the 13 prefecture-level cities of the province of Jiangsu in terms of GDP. (39) Under the current official evaluation system, which privileges economic targets, local officials in Changzhou have no choice but to stimulate growth at all costs.

\section{The real estate sector as pillar industry of the local economy}

In contrast to a slowing-down manufacturing industrial sector, the real estate sector in Changzhou City has become a pillar industry of the local economy since the mid-2000s. From 2006 to 2015, total investment in this sector reached 451.0 billion yuan with an annual investment of 45 billion yuan representing $20 \%$ of the fixed-asset investment in Changzhou City. ${ }^{(40)}$ Between 2006 and 2008, real estate investment increased at an annual growth rate of $34 \%$. This strong growth trend was interrupted by the global economic crisis. Thereafter, in response to national policy, the local government took measures to "save the market," such as lowering down payments for housing loans, which led to a new round of rapid growth between 2009 and 2013. In 2013, investment reached a peak of 69.9 billion yuan. In the same year, CCTV reported that Changzhou was a ghost city. Since then, the local government has redirected its land and housing policy, resulting in a decline in investment in the subsequent years.

The reliance of the local economy upon the real estate sector has been reflected in two aspects. First, from 2006 to 2015 , total revenue derived from land lease transactions amounted to 102.1 billion yuan. ${ }^{(41)}$ The ratio of land revenue to local budgetary revenue increased from $39 \%$ in 2006 to $90 \%$ in 2010 . By way of contrast, the average ratio in Chinese prefectural-level cities was $53 \%$, and $42 \%$ for those in the eastern regions in 2008. ${ }^{(42)}$ Changzhou's land revenue has contributed significantly to the development of the city's urban infrastructure during this period, which in turn has increased reliance on land finance.

Second, tax revenue related to real estate development ${ }^{(43)}$ and its ratio to local budgetary revenue have steadily increased during the last decade. In 2013, this revenue reached 11.5 billion, representing 28\% of Changzhou's local budgetary revenue (see table in Annex). According to an official of $\mathrm{BH}$ SREMC, the real estate sector was the only sector that contributed more than 10 billion yuan to the city's local tax revenue. ${ }^{(44)}$ By contrast, in firstand second-tier cities, an augmented and diversified tax base has made reliance upon real estate sector less significant. For instance, the ratio of real estate development-related tax to local budgetary revenue in Beijing remained below 20\% from 2008 to $2014{ }^{\text {(45) }}$ (Figure 3).

33. David Harvey, "The Urban Process under Capitalism:A Framework for Analysis," International Journal of Urban and Regional Research, Vol. 2, 1978, pp. 101-131; Hyun Bang Shin, "Contesting speculative urbanisation and strategising discontents," art. cit., pp. 509-516.

34. George C. S. Lin and Amy Y. Zhang, "Emerging spaces of neoliberal urbanism in China: Land commodification, municipal finance and local economic growth in prefecture-level cities," Urban Studies, Vol. 52, No. 15, 2015, pp. 2774-2798.

35. Huang Youqin, "Low-income housing in Chinese cities: policies and practices," The China Quarterly, Vol. 212, December 2012, pp. 941-964.

36. As of 2014, Changzhou Municipality included Changzhou City and two county-level municipalities under its leadership. Changzhou City consisted of Tianning, Zhonglou, Qishuyan, Xinbei, and Wujin districts. See MBSC, Yearbook of Changzhou Municipality (2006-2015), available at http://www.cztjj.gov.cn/class/OEJQMFCO (accessed on 23 January 2016).

37. Changzhou City Planning and Design Institute, Changzhou chengshi jianshe fazhan baogao, (Changzhou city construction development report [2008-2015]), internal document (in Chinese).

38. Documentary "Industry of Changzhou during thirty years of reform and opening-up," http://blog.sina.com.cn/s/blog_4b598a810100er2b.html (accessed on 6 May 2016).

39. The local GDP of Changzhou municipality ranked sixth in the province of Jiangsu, after Suzhou, Nanjing, Wuxi, Nantong, and Xuzhou in 2015.

40. BHSREMC, 2015 nian Changzhoushi fangdichan shichang yunxing qingkuang baogao, (Annual report of real estate market in Changzhou city (2015)), intern document (in Chinese)

41. Ibid.

42. George C. S. Lin and Amy Y. Zhang, "Emerging spaces of neoliberal urbanism in China: Land commodification, municipal finance and local economic growth in prefecture-level cities," Urban Studies, Vol. 52, No. 15, 2015, pp. 2774-2798.

43. Here, "tax revenue related to real estate development" refers to various taxes related to property transactions, including business tax, enterprise income tax, individual income tax, increment tax on land value, housing property tax, etc. Revenue derived from land lease transactions, which is part of extra-budgetary revenue for local governments, is not included.

44. Interview with an official of BHSREMC, 2 September 2015.

45. China index academy, "Land transfer fee of Beijing reached 200 billion yuan in 2015," http://land.fang.com/zt/201512/pdcrj.html, (accessed on 14 December 2016); Statistical Yearbook of Beijing 2008-2015. 
Figure 3 - Ratio of real estate development related tax to local budgetary revenue in Changzhou and Beijing (2007-2014)

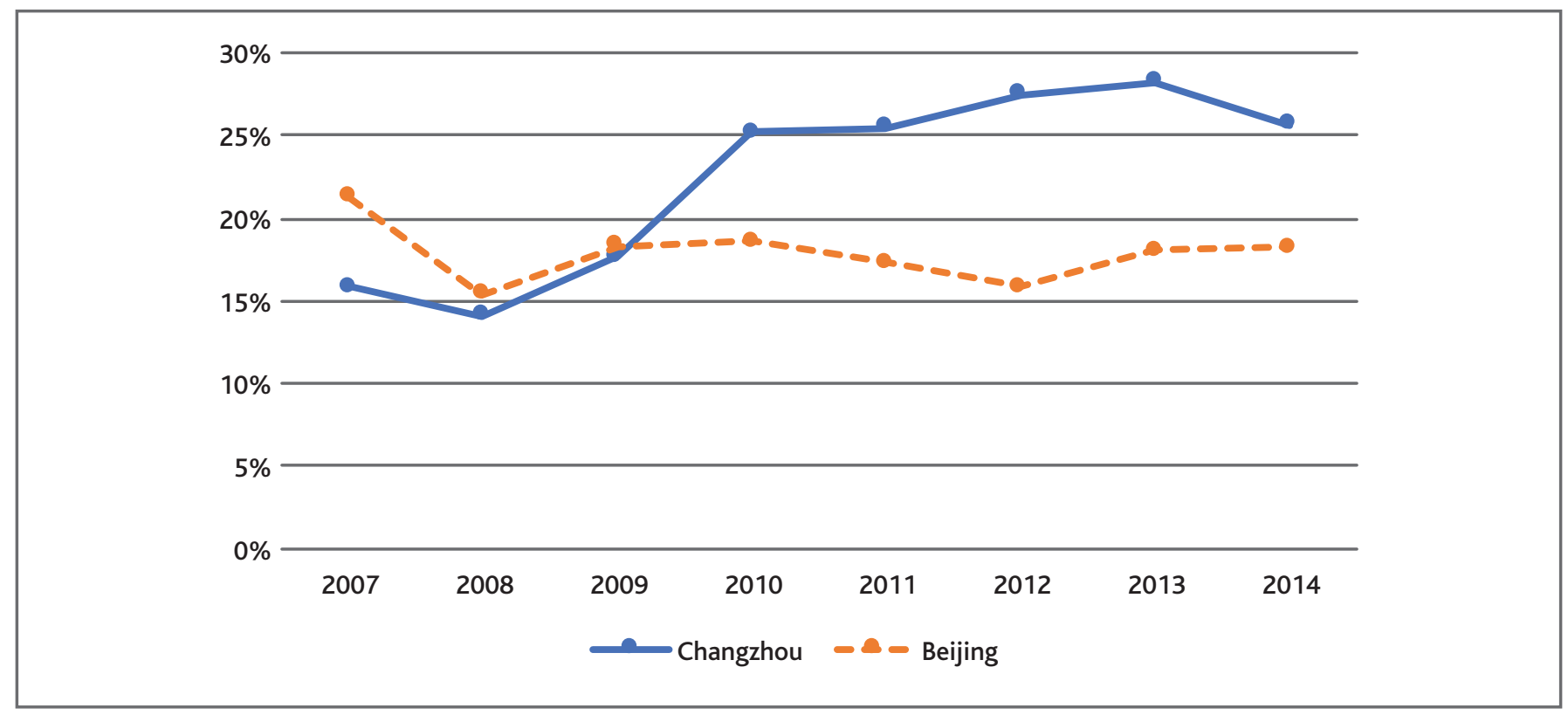

Source: BHSREMC, 2015; China index academy http://land.fang.com/zt/201512/pdcrj.html (accessed on 14 December 2016); Statistical Yearbook of Beijing, 2008-2015.

\section{Rapid expansion of residential and commercial land deviated from effective demand}

As in many third-and fourth-tier cities, planning has been used as an instrument to promote local development under entrepreneurial governance in Changzhou. Following the Changzhou Master Plan (1996-2010), which proposed "controlling the east and the west, developing the south and the north," two new districts, Xinbei and Wujin, were subsequently created north and south of the city proper. The new districts planned as growth poles for the city have become the major directions of urban expansion. This spatial structure, called "one centre plus two wings," was then consolidated in the Changzhou Master Plan (2011-2020). Under this expansionist approach, the urban development area (chengshi jianshe yongdi) of Changzhou grew from $261.38 \mathrm{~km}^{2}$ in 2008 to $326.57 \mathrm{~km}^{2}$ in 2014 , an increase of $25 \%$ within six years.

The rapid urban expansion in a short timeframe was achieved through large amounts of land being converted from rural collective land to urban state land by the local government. Thereafter, as the monopolistic supplier in the primary land market, the local government leased or allocated the serviced land to real estate developers. As shown in Figure 3, during the period from 2008 to 2012, the area of leased and allocated land for residential and commercial use more than tripled to 1,273 hectares in 2012. With respect to industrial land supply, although there was a short rise after the global crisis of 2008, it began to decline in 2011. As can be seen, since 2010 the evolution of commercial and residential land supply has deviated from that of industrial land (Figure 4).

Nevertheless, the supply of industrial land has been highly correlated with the growth rate of the industrial sector and the permanent population of Changzhou City. In the context of China's economic slowdown, there has been a decline in the growth rate of Changzhou's industrial sector. Accordingly, the growth of industrial land supply has declined, and has been accompanied by a deceleration in urban population growth (see table in
Annex). Considering the high homeownership rates among the existing urban population in Changzhou, ${ }^{(46)}$ effective housing demand has thus become saturated in such a context.

The oversupply of residential and commercial land has led to overbuilding in the housing and commercial sector. Compared to first- and second-tier cities, land prices have been moderate in Changzhou, attracting small and medium-sized real estate developers. Most of them have a local background and created a close relationship with the local government. For example, Xincheng Dichan is a residential real estate developer founded in Changzhou in 1993. With 21 residential projects for sale in Changzhou, it was ranked first in terms of value of sales in 2014. In order to maximise profits, most residential developers chose to build high-rise apartments.

Another factor in the construction frenzy in Changzhou is the 2010 completion of the Nanjing-Shanghai high-speed railway, which stops in Changzhou. The expected shorter journey time to Shanghai and Nanjing from Changzhou produced speculative interest in new real estate properties. The location of a new high-speed railway station was deliberately chosen in Xinbei New District with the aim of promoting urbanisation. However, compared to other cities in proximity to a mega-city, Changzhou, located between two mega-cities, has enjoyed less urban integration. ${ }^{(47)}$ As a result, speculative housing demand was not as strong as expected, leading to an oversupply of housing, especially near the new high-speed railway station in Xinbei.

Owing to insufficient housing demand, the sale of both commodity building (including office and commercial space) and commodity housing began to decline in 2010 (see table in Annex). Consequently, from 2010 to 2014,

46. Homeownership in Changzhou City was estimated at $96.1 \%$ according to a survey based on 2,167 urban households in Changzhou City in 2010. Source: "Homeownership in Changzhou City estimated at 96.1\%," http://www.chinanews.com/estate/2010/11-04/2634090.shtml (accessed on 30 December 2016).

47. Li Ying-cheng and Wang Xing-ping, "Hu-ning gaosu zoulang diqu de tongchenghua xiaoying jiqi yingxiang yinsu yanjiu" (Urban integration effect and its influencing factors in the highway corridor area between Shanghai and Nanjing), Modern Urban Studies, 84-120, 2013 (in Chinese). 


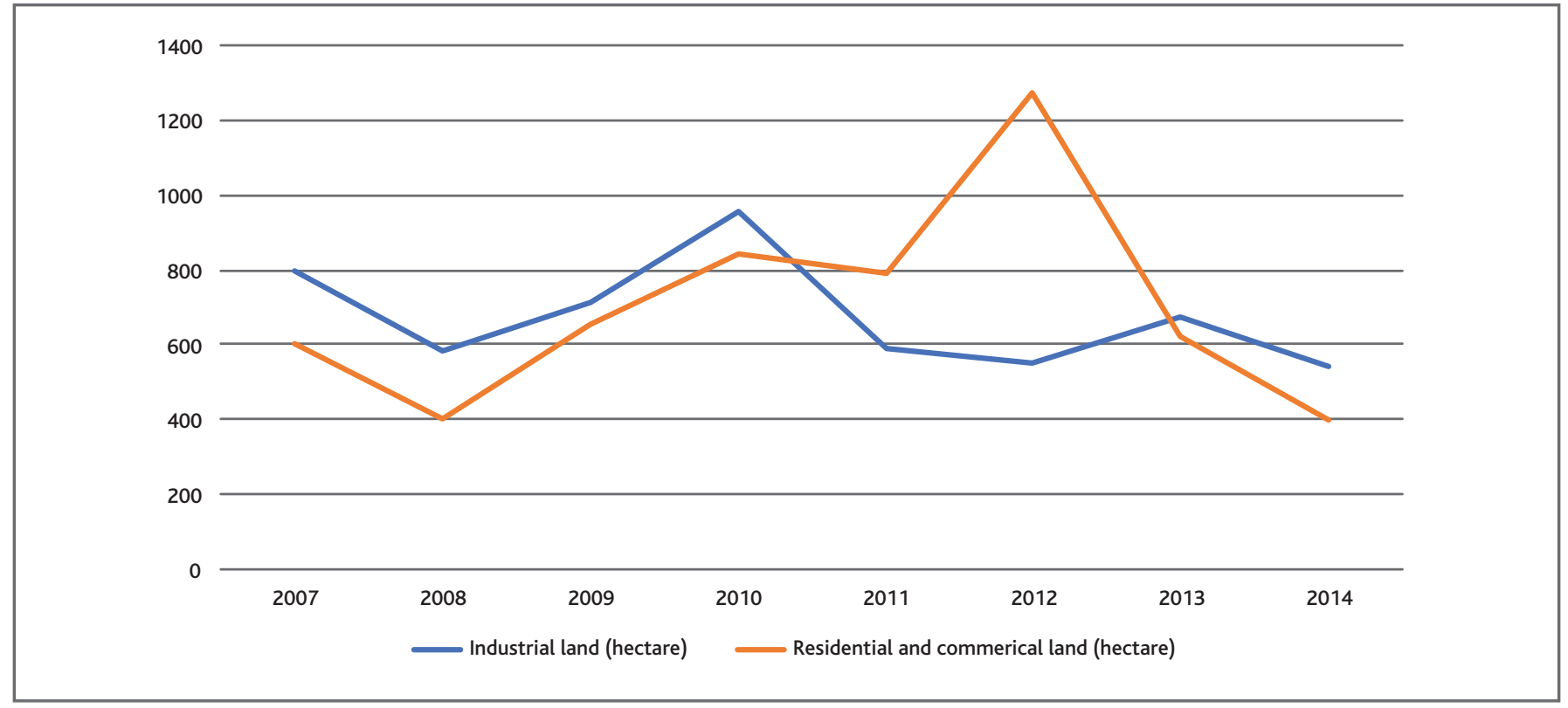

Source: Compiled by author according to CCPDI, 2015.

the stock of both commodity building and commodity housing kept increasing and reached record levels of 17.66 million $\mathrm{m}^{2}$ in 2014 and 10.12 million $\mathrm{m}^{2}$ in 2013 (see table in Annex). High stock levels in newly-built residential and commercial programs led to a high vacancy rate, and thus caused the ghost city phenomena.

\section{Focus on Wujin New District}

Despite high stock levels in newly-built residential developments in Changzhou, it would be exaggerating to consider the whole city a ghost city, given the great disparity between the city proper and the new districts in terms of population density. The problem of overbuilding has been concentrated in new districts, where urban expansion has been much faster than in the city proper during the last decade. In order to deepen our understanding of the process of forming a ghost city under entrepreneurial governance, we focus on Wujin New District, which was the major focus of the ghost city phenomenon in Changzhou reported by CCTV.

As the cradle of the Sunan model, (48) Wujin used to be a county located south of Changzhou City. Because of its early rural industrialisation based on township and villages enterprises (TVEs), it had a sound economic performance and was ranked second among the "Top 100 counties of China (zhongguo baiqiangxian)" (49) in 1992. In 1993, the Wujin County government office moved from Changzhou City proper to Wutang Town in Wujin in 1993, allowing Wujin to have a city-centre based on Wutang Town. In 1995, Wujin County was transformed into a county-level city, which consolidated its status as a relatively independent city. In 2002, Wujin was integrated into Changzhou as an urban district. Since then, Wujin New District has accelerated its urban development by multiplying its fixed asset investment by ten times. ${ }^{(50)}$ Nevertheless, settlement of Wujin New District proceeded at a slower rate than hoped. As a result, its population density is much lower than districts in the city proper (see Figure 1). The stock of newly-built commodity housing reached 2.8 million $\mathrm{m}^{2}$ in 2014 which was four times that of Zhonglou District and twice of that of Tianning District. ${ }^{(51)}$ In essence, this is the outcome of rapid urban expansion of the new district under entrepreneurial governance. In particular, the specifics of Wujin District in terms of its administrative status, planning strategy, and urban financing model have reinforced the land-driven growth machine.

First, compared to other urban districts, land control is more lax in Wujin. Although Wujin was integrated into Changzhou as an urban district in 2002, the district government managed to maintain its autonomy over the local fiscal budget, land management, and urban planning that should have been turned over to the prefecture-level municipality. ${ }^{(52)}$ This was due to the economic strength and local identity of Wujin, which raised the political stakes in negotiation. As a result, there has been less top-down control from the municipal government over the new district. For example, Wujin has applied a less strict land control policy compared with other districts. The aim was to stimulate local economic growth through aggressive land development. In 2013, the district government of Wujin leased 732 hectares of land and allocated 309 hectares of land for urban development, which represented respectively $60 \%$ and $62 \%$ of land leased and allocated in Changzhou. From 2008 to 2014, the urban development area of Wujin increased by $60 \%$ to reach an area of $110.0 \mathrm{~km}^{2}$ in 2014. ${ }^{(53)}$ This has already exceeded the 100 $\mathrm{km}^{2}$ of urban development area planned for 2020.

48. The orthodox Sunan model attributes the development of Sunan (southern Jiangsu Province) to local state-directed township and village enterprises (TVES). It has been conceptualised as local state corporatism.

49. The evaluation of the "Top 100 counties of China" was based on comprehensive competiveness of county-level divisions, including economic and social indicators.

50. Statistical Yearbook of Wujin 2002-2011.

51. BHSREMC, 2015 nian Changzhoushi fangdichan shichang yunxing qingkuang baogao (Annual report of real estate market in Changzhou city [2015]), internal document (in Chinese)

52. Interview with an urban planner in Changzhou City Planning and Design Institute, 5 September 2015.

53. Changzhou City Planning and Design Institute, Changzhou city construction development report (2008-2015), Changzhou chengshi jianshe fazhan baogao, internal document (in Chinese). 


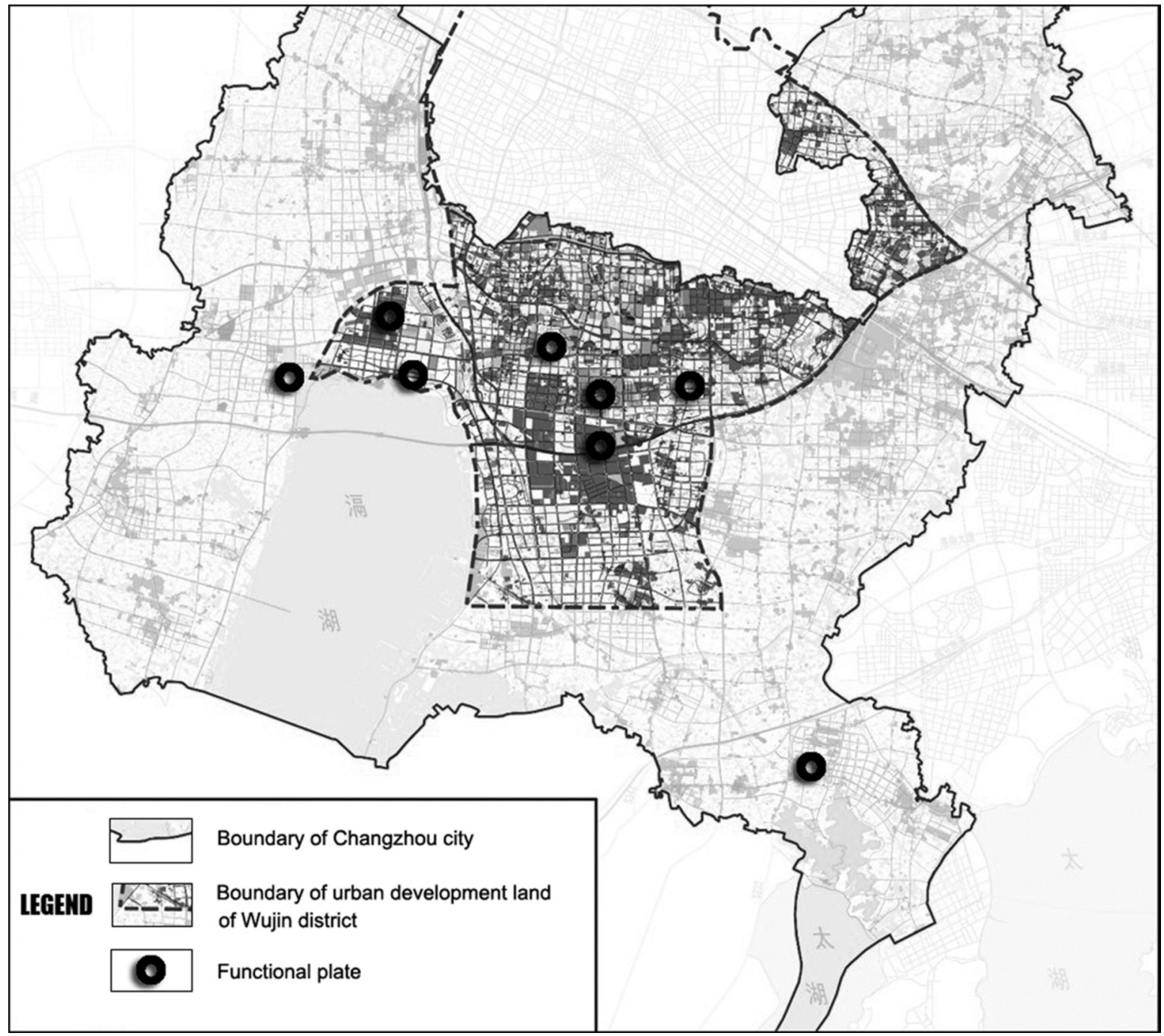

Source: Compiled by author according to CCPDI, 2015.

Second, urban development in Wujin did not follow a plan that gave a holistic view of the new district. Originating with TVEs (mostly small-and medium-size industrial units), the industrial development of Wujin grew out of control and was scattered throughout the territory. In order to rationalise its industrial development and build a modern new city, the Changzhou Master Plan (2011-2020) proposed to plan the new district as Changzhou city's southern wing with three functional zones: an urban core in the centre of the district, a western zone near Gehu Lake for tourist, ecological, leisure, and residential functions, and a southern zone for high-tech industrial and logistic activities. In reality, instead of following the Master Plan, the district government proposed organising urban development around eight functional "plates" (bankuai). These plates included three tourist zones, two ecological and agricultural parks, two industrial parks, and one techno-city. In this way, the district government, which functions like a corporation, attempted to materialise its economic development target in the specific urban space. However, this has led to a fragmented land use pattern (Figure 5) that consumed large amounts of land but attracted insufficient population. Moreover, the plates suffer from poor connections between them, making the spatial structure of the new district less compact than for districts in the city proper.
Third, under entrepreneurial governance, local government-run financing vehicles (LGFVs) have been used to support the urban development of the new district. Unlike new districts in first- and second-tier cities, Wujin New District has gained little support from the central or provincial governments. For example, gaining the title of "special zone" or "experimental zone" for national strategy allows application for preferential policies and can stimulate the inflow of investment. ${ }^{(54)}$ In order to support the cost of urban development, the district government had to seek capital from private investors. Against this background, eight LGFVs have been set up, corresponding to the eight functional plates ${ }^{(55)}$ (Figure 5). While the creation of LGFVs is a common practice in Chinese cities, Wujin is exceptional in creating one LGFV devoted to each functional plate. For instance, the plate called "Changzhou Techno-city," located in the centre of Wujin District, is managed by the LGFV "Changzhou Techno-city Investment Corporation." Each LGFV followed the principle of "self-financing, self-devel-

54. Wu Fulong, Planning for Growth: Urban and Regional Planning in China, op. cit., pp. 50-72.

55. Mai Jing and Zhang Jingxiang, "A research on new city spatial development led by local entrepreneurialism: The case of Wujin's new city district" (difangzhengfu zhudaoxia de xincheng kongjian kaifa yanjiu: jiyu changzhoushi wujin xinchengqu de shizheng), Urban Planning Forum, Vol. 3, 2013, pp. 54-60 (in Chinese) 
opment, and self-management." (56) This means that each LGFV is equivalent to a corporation in charge of the urban development within the plate. Meanwhile, the leader of each LGFV is a government official, which ensures the leadership role of the local government in the development of the functional plate. This entrepreneurial governance allowed the functional plates to gain financing from the market, which accelerated the urban development of Wujin at the early stage. Nevertheless, this became problematic with the progress of the urban project. Each LGFV functioned like a company, maximising economic interest and leading to more competition than coordination between them. In particular, due to overlapped functions and similar development strategies, in order to attract investors, the plates had to "sell" land at a cheap price. This accelerated the expansion of each plate. In addition, under the self-financing principle, the plates became highly dependent on residential and commercial real estate development, because in order to achieve financing equilibrium, they had to lease sufficient residential and commercial land to balance the cheap land leased to investors in the targeted activities in the plate. Thus, the residential and commercial projects were programmed based on the financing needs of each LGFV rather than on effective demand. This resulted in an abundance of unoccupied residential and commercial projects in each plate.

In short, the case of Wujin shows that the new districts of third- and fourth- tier cities have pushed the land-driven growth machine to a new level through more lax land control, more growth-oriented urban spatial plans, and more entrepreneurial governance. Consequently, the ghost city phenomenon is more significant in these newly built urban areas.

\section{Changzhou redirects its land and housing policy in the context of "New Normal"}

Recent remarks by President Xi Jinping regarding China's "New Normal" have heralded China's entrance into a new era of slower economic growth where the method of stimulating economic growth through large-scale public investment incentives is no longer as simple as before. In response, the central government has launched a series of policies around the target of reducing stock. The Ministry of Land Resources has stated that land quotas for commodity housing development need to be reduced in cities with excess housing stock. ${ }^{(57)}$ One of the decisions of the 11th meeting of the Central Finance and Economy Leading Group was to facilitate housing purchases for rural migrants so as to expand effective housing demand. ${ }^{(58)}$

In the case of Changzhou, owing to its notorious reputation as ghost city, the municipal government became a pioneer in redirecting land and housing policies in the new context. Since 2013, five measures have been taken to reduce housing stock: first, control land supply. In 2014, the municipal government said it would stop land supply for three years, except for land lease contracts signed in 2013. This had a great impact on land revenue and the real estate sector in Changzhou. In 2015, land revenue was reduced to 0.6 billion yuan, only $2 \%$ of that in 2010 (see table in Annex). Investment in the real estate sector declined by $27 \%$ from 2013 to 2015 . Second, control the supply of newly-built commodity housing. Specifically, the municipal government required developers to postpone the delivery of residential projects. Consequently, in 2014, the supply of newly-built commodity housing decreased by $30 \%$ in 2014 and by $40 \%$ in 2015. ${ }^{(59)}$ Third, use commodity housing for social housing and resettlement housing programs. Given the large stock of commodity housing, the government considered it no longer necessary to develop specific housing programs for social purposes or to resettle expropriated households. Instead, the government began to grant a housing allowance or housing voucher to the targeted population so they could purchase a home on the market. Fourth, lower the minimum down payment ratio in housing loans. In order to support housing purchases, the government reduced the minimum down payment ratio in housing loans from the Housing Provident Fund Program ${ }^{(60)}$ to $20 \%$ in 2015 . Fifth, diversify the housing supply. To satisfy people's diversified demand, the government encouraged developers to diversify their housing products. Apart from high-rise apartments, developers are encouraged to develop other housing developments such as individual houses, retirement homes, etc.

Among these measures, land supply control is the most severe, and has a direct effect on housing stock levels. In 2014, the stock of commodity housing began to decline. Meanwhile, the local government paid a heavy price in terms of land revenue. Consequently, there has been greater pressure on local public finance. In 2012, the local debt of the Changzhou municipal government was estimated at 35.4 billion yuan, representing $90 \%$ of local GDP. ${ }^{(61)}$ Deprived of land revenue, the local government will be forced to increase the debt level, putting the government's financial stability at risk. Without profound reform of the land development system, land supply control tends to be a temporary measure rather than a sustainable solution. Similarly, restricting the supply of newly-built commodity housing is likely to be a temporary action. On the other hand, there have been encouraging changes on the supply side, such as the granting of housing allowances and diversifying the housing supply.

\section{Discussion and conclusions}

This paper updates the ghost city phenomenon of mainland China through an in-depth empirical study of a third-tier city, Changzhou. As demonstrated by this case, overbuilding is related to aggressive urban expansion and low housing demand during the last decade. In essence, this is an outcome of a land-driven growth machine under entrepreneurial governance. Pushed by the current official evaluation system centred on economic targets, the local authorities have controlled land quotas based on local economic need rather than effective housing demand. They have endeavoured to maintain the prosperity of the real estate market, which constitutes the pillar industry of the local economy. These practices caused an over-reliance on land finance and the real estate sector. What makes the situation worse is China's economic slowdown since 2010. Under these conditions, housing demand in Changzhou has become much lower than in first- and second-tier cities due to its sluggish manufacturing industry and high homeownership rate, while the city's reliance on land finance and the real estate sector has been

56. Mai Jing and Zhang Jingxiang, "A research on new city spatial development led by local entrepreneurialism: The case of Wujin's new city district" (difangzhengfu zhudaoxia de xincheng kongjian kaifa yanjiu: jiyu changzhoushi wujin xinchengqu de shizheng), Urban Planning Forum, op. cit.

57. Huang Tao, "Ministry of Land and Resources required to reduce land supply for commodity housing development," http://ehsb.hsw.cn/shtml/hsb/20160111/565141.shtml (accessed on 20 May 2016).

58. Cai Yunkun, "More than twenty provinces set up policies to encourage rural migrants to purchase homes," http://business.sohu.com/20160408/n443660932.shtml (accessed on 20 May 2016).

59. BHSREMC, 2015 nian Changzhoushi fangdichan shichang yunxing qingkuang baogao, (Annual report of real estate market in Changzhou city[2015]), internal document (in Chinese).

60. The Housing Provident Fund Program is a compulsory savings program in Chinese cities in which employers and employees contribute a certain percentage of the employee's salary to a special account. In return, employees can get low-interest mortgage loans for housing purchases.

61. Generally, the debt level of local governments is not transparent. There is no official information on the debt level in Changzhou. The estimate of local debt at 35.4 billion yuan was found in a Chinese forum. Source: "local debt levels of Nanjing, Wuxi, and Changzhou," https:// www.zhihu.com/question/31693175 (accessed on 21 May 2016). 
more significant than in first- and second-tier cities. Because the ratio of land revenue and real estate-related tax to local budgetary revenue in Changzhou is higher than in first- and second-tier cities, the oversupply of land and massive investment in residential real estate during this period has led to excess housing stock in Changzhou.

Nevertheless, it is an exaggeration to consider the whole city a ghost city. Compared to the city proper, Wujin New District has concentrated the problem of overbuilding. The land-driven growth machine has been pushed to a new level owing to more lax land control, a more growth-oriented urban spatial plan, and more entrepreneurial governance in the new district. The eight LGFVs for the eight functional plates show an urbanism subordinated to economic and financial objectives rather than to people's needs.

Under the New Normal, Changzhou has become a pioneer city in redirecting its land and housing policies. Several measures have been taken to reduce housing stock, including strict controls on land supply. Although this had a direct effect on housing stock, the local government has paid a heavy price in terms of land revenue. With greater pressure on local public finance, the local government is likely to raise its debt level, which has already been very high through its LGFVs. This situation could potentially trigger a debt crisis. Other measures such as the granting of housing allowances and diversifying the housing supply are encouraging. However, these measures do not change the land-driven growth mechanism.

In other word, more profound reforms are needed for a paradigm shift from growth-oriented to people-centred urbanism. First, the current official evaluation system centred on local economic growth has to be reformed to a more comprehensive system. Second, changes to the existing public finance system are needed. The monopoly local governments have over land supply, and their dependency on land for revenue, have to be broken. ${ }^{(62)} \mathrm{A}$ new system of tax and revenue sharing between central and local governments should be established to guarantee financial resources to local governments in terms of infrastructure construction and social service provision. ${ }^{(63)}$ The above two reforms will facilitate changing the fate of local state entrepreneurialism and eventually reduce the liabilities of local governments to a reasonable level. In 2015, the Chinese government began to restructure the liabilities of local governments through debt swaps, which have made local governments' mountain of debt look a little safer. ${ }^{(64)}$ But the root of the problem cannot be tackled without fundamental reform of the official evaluation and fiscal systems.

In addition, institutional barriers on rural migrants in their urban destinations should be removed. For example, they should have access to social housing, which is currently intended exclusively for residents with urban hukou in most of Chinese cities. Also, equal treatment in terms of housing loans between urban and rural residents should be restored so as to facilitate home purchases by rural migrants in their urban destinations. Last but not least, local authorities of third- and fourth-tier cities should be more committed to restructuring and upgrading local industry under the New Normal. These reforms are necessary to transform growth-oriented urbanisation into a people-oriented one and to achieve the more sustainable and balanced growth advocated by the Chinese government.

\section{Li Mingye, who completed a doctorate at the Paris School of} Urbanism, is a postdoctoral researcher at the Urban Planning and Research Institute of the Federal University of Rio de Janeiro, Brasil.

Instituto de Pesquisa e Planejamento Urbano e Regional, da Universidade Federal do Rio de Janeiro, Av. Pedro Calmon, $\mathrm{n}^{\circ} 550$ Prédio da Reitoria $5^{\circ}$ andar Cidade Universitária - Rio de Janeiro, Brasil (limingyenju@gmail.com).

Manuscript received on 10 June 2016. Accepted on 29 December 2016.

62. Huang Youqin, "Low-income housing in Chinese cities: Policies and practices," The China Quarterly, Vol. 212, pp. 941-964, 2012

63. Yu Hong, "China's 'Ghost Cities'," art. cit., pp. 33-42, 2014.

64. "China's local government debt: Defusing a bomb," The Economist, http://www.economist.com/ blogs/freeexchange/2015/03/china-s-local-government-debt, (accessed on 17 December 2016).

\section{Summary table of the statistical data related to land management, industrial sector, population and real estate market in Changzhou city (2007-2014)}

\begin{tabular}{|c|c|c|c|c|c|c|c|c|c|}
\hline & & 2007 & 2008 & 2009 & 2010 & 2011 & 2012 & 2013 & 2014 \\
\hline \multirow{2}{*}{$\begin{array}{c}\text { Area of leased } \\
\text { and allocated land* }\end{array}$} & Industrial land (hectare) & 798 & 582 & 714 & 956 & 591 & 552 & 677 & 542 \\
\hline & $\begin{array}{l}\text { Residential and } \\
\text { commercial land (hectare) }\end{array}$ & 604 & 403 & 654 & 843 & 792 & 1273 & 620 & 399 \\
\hline \multicolumn{2}{|c|}{ Annual land revenue (million yuan)** } & 10181 & 5700 & 18115 & 25692 & 13335 & 14246 & 7832 & 1769 \\
\hline \multirow{2}{*}{$\begin{array}{l}\text { Evolution of industrial } \\
\text { sector and permanent } \\
\text { population*** }\end{array}$} & $\begin{array}{l}\text { Growth rate of } \\
\text { industrial sector }\end{array}$ & $16.2 \%$ & $12.10 \%$ & $10.80 \%$ & $13.2 \%$ & $12.2 \%$ & $11.7 \%$ & $11.2 \%$ & $9.5 \%$ \\
\hline & $\begin{array}{c}\text { Growth rate of } \\
\text { permanent population }\end{array}$ & $3.14 \%$ & $1.66 \%$ & $1.28 \%$ & $4.21 \%$ & $1.43 \%$ & $0.87 \%$ & $0.17 \%$ & $0.13 \%$ \\
\hline \multirow{4}{*}{$\begin{array}{l}\text { Evolution of the sales } \\
\text { and the stock of newly } \\
\text { built commodity building } \\
\text { and housing**** } \\
\text { (million } \mathrm{m}^{2} \text { ) }\end{array}$} & $\begin{array}{l}\text { Sales of commodity } \\
\text { building }\end{array}$ & 6.65 & 5.23 & 10.83 & 9.11 & 6.34 & 7.96 & 8.31 & 8.27 \\
\hline & $\begin{array}{l}\text { Sales of commodity } \\
\text { housing }\end{array}$ & 4.95 & 4.06 & 8.49 & 7.11 & 5.05 & 6.58 & 7.12 & 6.90 \\
\hline & $\begin{array}{l}\text { Stock of commodity } \\
\text { building }\end{array}$ & 9.94 & 13.23 & 10.02 & 9.69 & 12.06 & 13.60 & 16.87 & 17.66 \\
\hline & $\begin{array}{l}\text { Stock of commodity } \\
\text { housing }\end{array}$ & 5.96 & 8.00 & 5.27 & 4.87 & 6.79 & 7.78 & 10.12 & 10.09 \\
\hline
\end{tabular}

*compiled by the author according to CCPDI, 2015 ** BHSREMC, 2015; the annual land revenue in Changzhou was 4632 million yuan in 2006 and 637 million yuan in 2015 *** compiled by the author according to the MBSC (2006-2015), CCPDI, 2015 **** BHSREMC, 2015. 